Abstracta Iranica Abstracta Iranica

Revue bibliographique pour le domaine irano-aryen

Volume 26 | 2005

Comptes rendus des publications de 2003

\title{
An Historical Atlas of Central Asia. Handbuch der Orientalistik, Section Eight: Central Asia, Volume Nine, Leiden \& Boston, Brill, 2003, 109 pp.
}

\section{Robert McChesney}

\section{(2) OpenEdition}

\section{Journals}

Édition électronique

URL : http://journals.openedition.org/abstractairanica/2545

ISSN : 1961-960X

Éditeur :

CNRS (UMR 7528 Mondes iraniens et indiens), Éditions de l'IFRI

Édition imprimée

Date de publication : 15 mai 2005

ISSN : 0240-8910

\section{Référence électronique}

Robert McChesney, «An Historical Atlas of Central Asia. Handbuch der Orientalistik, Section Eight: Central Asia, Volume Nine, Leiden \& Boston, Brill, 2003, 109 pp. », Abstracta Iranica [En ligne], Volume 26 | 2005, document 176, mis en ligne le 08 décembre 2005, consulté le 25 septembre 2020. URL : http://journals.openedition.org/abstractairanica/2545

Ce document a été généré automatiquement le 25 septembre 2020.

Tous droits réservés 


\title{
An Historical Atlas of Central Asia. Handbuch der Orientalistik, Section Eight: Central Asia, Volume Nine, Leiden \& Boston, Brill, 2003, 109 pp.
}

\author{
Robert McChesney
}

1 Every student of Islamic Central Asian history must have in their reference collection three books: Persidskaya Literatura: Bio-bibliograficheskii Obzor, Bibliography of Islamic Central Asia, and this historical atlas - all three, remarkably, the work of the dean of Islamic Central Asian historical studies, Prof. Yuri Bregel. This atlas should be the model for any future historical atlases of any region of the Islamic world.

2 The atlas is remarkable because it combines a lucid, detailed, and precise historical narrative with accompanying maps. Every point in the narrative may be followed on its companion map and every settlement, campaign route, battle, and topographical feature on the map is illustrated in the accompanying narrative. One is at a loss to think of any comparable work. An Historical Atlas of Islam (1981 edition) lacks a useful narrative to explain the maps, which in any event are much too general. Irfan Habib's An Atlas of the Mughal Empire although rich in the topography of economic activity, also lacks an explanatory narrative.

3 The atlas contains forty-eight maps in all, thirty-five of which illustrate the political history of the region. The time periods covered by each map range from (at the long end of the spectrum) four centuries (3rd-6th centuries - map 6) to as little as five years (map 45 "Revolution and Civil War in Western Turkestan"). Much more commonly, the maps encompass a century or half century. The earliest map traces the campaigns of Alexander (map 3) and the latest is "Central Asia to the year 2000" (map 47). The texts range somewhat in length but generally are about 1,500 words.

4 The remaining twelve maps are worth listing to give a flavor of the comprehensiveness of this atlas. "The principal geographical features and provinces" make up map 1. Map 2 is "Major archeological sites". Map 34 details "The trade routes of central Asia". Maps 
35, 36a, 36b, 37, 38, and 39 locate the Özbek, Turkmen, Qazaq, and Qirghiz tribes and their movements in the 19th and 20th centuries. Maps 40, 41 and 42 illustrate the 19th century cities of Bukhara, Samarqand, and Khiva respectively and map 43 locates the maj or monuments of Islamic architecture.

5 There is nothing with which to find fault in this magnificent work. Beyond its obvious value as a source for spatial references, it provides concise but encyclopedic coverage of the history of Central Asia. The treatment of the Mongol and post-Mongol period is particularly valuable as it traces with great clarity the histories of all the Mongol successor polities (the uluses and ordas) and their political legacies to the region.

The maps, all in full-color, are extraordinarily well done. In all but the map devoted to geography topographical features are muted. While they may be easily discernible, they never intrude on the information for which each map was designed, unlike the 1981 edition of An Historical Atlas of Islam where the topographical features are drawn and colored in such a way as to overwhelm the other information the map is supposed to provide. (As a technical recommendation - in the event that the Atlas should go to another edition, this reviewer would have found the work much easier to use and enjoy had it been laid out and bound differently. Except for maps 33 and 44, the layout of the maps is in "landscape" [horizontal] format while the accompanying text on the facing page is in "portrait' [vertical] format. This means the reader is continually turning the volume ninety degrees in order to connect the map and text. If the volume were bound on the shorter axis and the text was divided into two or three columns and also laid out horizontally, the connection of map and text would be seamless and the pleasure of the reader, already great, would be further enhanced.)

INDEX

Thèmes : 4.0. Généralités

\section{AUTEURS}

ROBERT MCCHESNEY

University of New York 